\title{
QUANTITATIVE ANALYSIS OF SPORTS INJURIES IN KOSOVSKA MITROVICA
}

\section{AUTHORS}

Stanić $Đ .^{1}$, Božović A. ${ }^{2}$, Vasić A. ${ }^{2}$

${ }_{1}$ University of Eastern Sarajevo, Faculty of Physical Education and Sports, Eastern Sarajevo, Republic of Serbska

${ }^{2}$ Medical Faculty, University of Priština, Kosovska Mitrovica, Serbia

\section{SUMMARY}

The extent and frequency of sports injury is often influenced by a variety of exogenous and endogenous factors, including poor physical fitness muscular imbalance, anatomical abnormalities, poor nutrition, and periods of intensive growth. The competing ability must be carefully estimated after injury, taking into account the nature and type of injury, the pain sensitivity as well as the time that passed from the injury. This is usually accomplished by the comparison with the uninjured limb, as well as with functional examinations. We evaluated the frequency and the type of injury in 112 sportsmen in Kosovska Mitrovica. Our results indicate that accurate evaluation of competing ability after injury is an important preventive measure in further sports activities.

Keywords: sport, injury, prevention

\section{INTRODUCTION}

Sports injuries hold a high position in the order of injury frequency in the today's world, which is why their prevention is of great importance as well as the procedure right after the injury has occurred. By their nature, sport injuries are most often not severe but can adversely influence the competing abilities due to the false belief that it is possible to heal faster than the natural processes allow. The recovery process of the athlete must be complete to avoid the risk of re-injury, which in these cases is usually more severe than the previous one [1].

Injuries that occur in athletes occur in everyday life as well, even though the athletes are typically more exposed to the risks of injury, which is a rare occurrence in other people, excluding some occupational injuries or damages and injuries that occur in car accidents. Since sports injuries are a widespread phenomenon, the rules of their prevention have been established. The treatment of sports injuries is specific, and its objectives are clearly defined: the injured athlete needs to be fully recovered, and the period of disability depends on the assessment of his capabilities [2,3]. Athlete's reaction to injury is different than is the case of the ordinary life circumstances. An athlete is often ready to play regardless of the injury which, in ordinary life, would require rehabilitation. The professionalization of sports has even more intensified all these problems, since it is now related to making money for the athlete himself or the club and everyone in it.

There are no universal methods that can accelerate the natural course of treatment, but there are a lot of them that can prolong it. Compliance with the natural course of treatment is often a source of conflict between the physician and the club, the coaches, the media, etc., and the pressure is even greater with the higher quality of the athletes in question. Year after year, the strength and the speed in sports have grown and with them the exposure to injuries as well. This is proven by the fact that the senior world records of 30 years ago are now achieved and surpassed by the juniors, even in training. Given the significant involvement of youth in sports activities, the aim of this paper is to present the basic characteristics of sports injuries which may contribute to the prevention of their occurrence.

\section{MATHERIAL AND METHODS}

This paper uses data on sports injuries in the time period between 2006 and 2013 that were obtained from Priština Medical Center, the Department of Surgery and Orthopedics, and Kosovska Mitrovica Health Centre, the Department of Orthopedics. The study was done in accordance with the Declaration of Helsinki. The paper used data related to the recreational athletes.

Parametric and non-parametric methods were used in the evaluation of the obtained data. A significant difference was considered to be any difference between groups at $p<0.05$.

\section{RESULTS}

In the observed five-year period, from 2005 to 2013, 112 athletes ( 87 men and 25 women) were cared for at 
Priština Medical Center, the Department of Surgery and Orthopedics, and at Kosovska Mitrovica Health Centre, the Department of Orthopedic Surgery. The studies covered injuries sustained during or immediately after training or competition. Distortions, dislocations and ligament ruptures were the most common injuries, accounting for $60 \%$, followed by fractures of the lower extremities $(13 \%)$, contusions, open or superficial wounds $(12 \%)$, fractures of the upper extremities $(5 \%)$, abdominal and thorax injuries (4\%), head injuries (3\%) and other injuries (5\%). Most frequently affected were the knees, thighs, ankles, shoulders, hands, head and feet.

\section{Chart 1. The distribution of sports injuries according to sports}

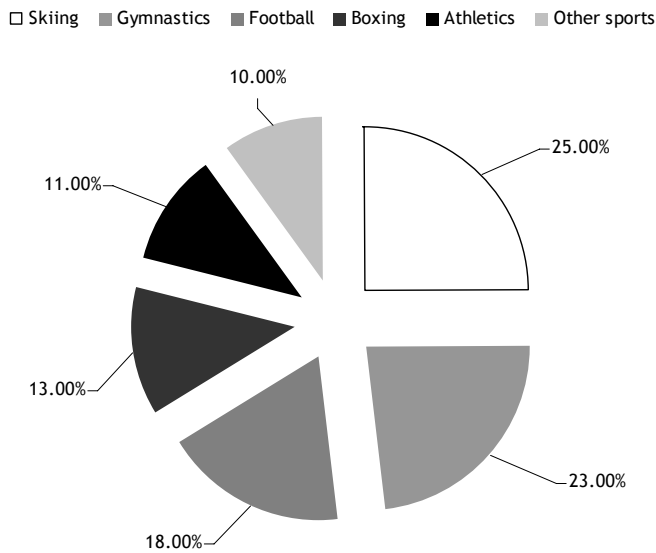

The distribution of injuries according to sports shows that the injury was most common among skiers, then practitioners of gymnastics apparatus, football players, boxers, runners and a smaller percentage of the other athletes (Chart 1 ). In relation to age, the most common injuries occurred in athletes between 21 and 30 years of age (Chart 2).

Chart 2. The distribution of sports injuries according to sports

—under 20 years $\square 21$ to 30 years $\quad 31$ to 40 years $\square$ Over 40 years

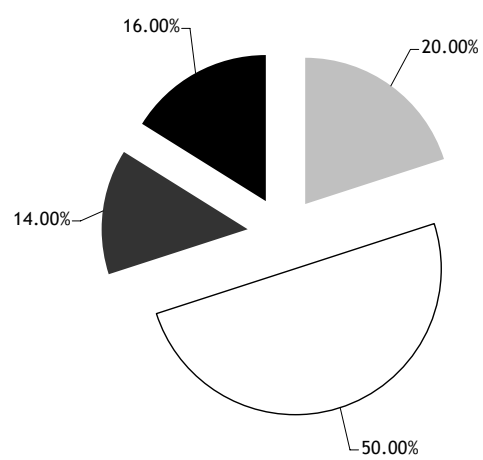

Generally speaking, the beginners, the inexperienced, the careless, the overworked, the untrained, then those with poor self-control or under the insufficient control of coaches and judges are more prone to injury in any kind of environment, but especially on rough terrain and without their protective equipment.

\section{DISCUSSION}

According to literature data, sports injuries account for $10 \%-15 \%$ of the total number of injuries, and most frequently affected body parts are knees, thighs, ankles, shoulders, hands, head and feet [5]. The results of our study confirm these findings showing that the most common injuries were distortions, dislocations and ligament ruptures of the knee, thigh and the ankle joint.

Sports injuries can significantly affect the competitive ability of the individual $[4,5]$. In endogenous injuries the anatomical and physiological changes in tissue are caused by fatigue and stress, while the exogenous injuries are caused by the effect of external forces or agents. In acute sports injuries that occur as a result of the immediate action of a strong force that exceeds the compensatory ability of our body and leads to the mechanical damage of the tissue, we noted that the especially affected was the soft tissue (muscles, ligaments, tendons) of the locomotor system that gives support to our joints and prevent injuries $[6,7]$.

In contrast, chronic sports injuries are the result of repeated, frequent action of force, with the repetitive stereotyped movements, characteristic of a certain type of sport [8]. The action of force on the local tissue is cumulative, causing repeated microtraumas until they overcome the ability of the local tissue to regenerate. Overstrain injuries predominantly affect tissues that tend to suffer from repetitive motion and accumulation of mechanical stress during sport activities: the tendons, tendon attachment to the bone, localities where the mechanical friction and pressure are pronounced, parts of the bone on which the strain forces intersect. The most common types of injuries in overstrain injuries are tendinitis (the inflammation of the tendon), enthesitis (the inflammation of the tendon attachment to the bone), bursitis (ie, the inflammation of the mucous sack whose role is to amortize the effects of existing friction and pressure in the locomotor system) and stress fractures that result from the repeated mechanical stress on certain parts of the bone.

The overstrain of the locomotor apparatus and the localization of the injury may be characteristic for a particular type of sport, which led to certain characteristic terms for the injuries (tennis elbow, swimmer's shoulder, jumper's knee, and the like). The causes that lead to the occurrence of these injuries may be internal, related to a specific athlete, or external, related to the training conditions. Internal causes of overstrain injuries can, for example, be found in previous injuries. Tissue weakened by previous injury is a weak spot and in risk of new injuries. Complete rehabilitation includes not only pain relief, but restoring the full function of the injured part. Poor physical fitness, muscle imbalance, anatomical abnormalities, poor nutrition and periods of intensive growth also act as precipitating factors of injury.

Physically poorly prepared athletes are more prone to injuries, and these injuries mostly occur at the beginning of the season $[8,9]$, which is explained by muscle imbalance. Muscle imbalance occurs between the muscle groups that perform various movements of a particular body part - muscles antagonists (the muscles on the back 
(hamstrings) and front (quadriceps) of the upper leg). The consequence of this imbalance is improper function of this part of the body, followed by overstrain of the active structures, anatomical abnormalities usually in the feet and knees region, then thighs and spinal cord. Deformities disrupt the normal movement patterns and lead to compensatory overstrain of the surrounding soft tissue structures. The deficit in nutrient intake reduces the capability of the organism, both in training and in recovery. This is why proper nutrition and supplementation need to be provided to compensate for all the macro-and micronutrients. [9]

The causes of overstrain that lead to sports injuries may originate from training errors, inadequate equipment and the improper training structure. The most common mistakes in training are excessive training and intensity [10]. Insufficiently elastic tissues are most susceptible to injury, which is why warming up at the beginning of training and stretching at the end of training are of great importance in prevention of sports injury. Warming up at the beginning of the training involves increasing the blood flow through the muscles, the local temperature and the elasticity of the tissue. Stretching at the end of the training increases the elasticity of the soft tissue, resulting in muscle relaxation and improved blood flow to the muscles.

In the acute stage, all sports injuries are treated by similar methods $[7,8,11,12]$, which are cooling, compression, elevation and immobilization of the injured limb. The cooling should be applied during the 24-48 hour period from the time of injury, mainly for 15 minutes, 3 times a day. If cooling is applied for a longer period, then the following principles should strictly be followed: the cooling method should be dry (ice is placed in a special rubber container, a hot water bottle, or in a simple plastic bag which should be sealed to prevent water leaks when the ice starts melting and the bag is then wrapped in a towel); it is important that there is an insulator between the ice and the skin which will not allow a direct skin contact with ice, thus avoiding the occurrence of frostbite.

In football players, the typical injuries are caused by indirect mechanisms; they are mostly located in the thigh, knee and ankle regions. Knee injuries account for $60 \%$ of all football related injuries. The reason can be found in the usage of studs on football boots, which prevent foot rotation when on the ground. It provides stability and support when kicking, but the excessive rotational forces are plated on the knee joint, resulting in injuries of the meniscus and ligaments. In hockey, which is a much rougher sport than football, there are no meniscus related injuries [13]. The second highest incidence of injury occurs on the ankle, and its ligaments. The protective bandage helps in the prevention of ankle ligament injuries. The most common cause of pain in the groin is the difference and imbalance of the strong thigh and the weak abdominal muscles, resulting in overstrain of inguinal ligaments and the opening of the inguinal canal (possible hernia), which causes pain.

The strength-building training leads to hypertrophy and the increase in muscle strength, increasing the stability of the joints and the resistance to injury. Properly dosed training and gradual progress in training prevent muscle and tendon injuries [12,13]. Stretching exercises provide for a full range of motion in the joints, also preventing muscle and tendon injuries. The supplementation and proper nutrition contribute to a better quality of soft tissue structure by increasing their collagen content. Collagen is responsible for the firmness of the soft tissue, wherein vitamin $C$ is necessary for the proper collagen synthesis. The supplementation by collagen, glucosamine and hyaluronic acid products showed positive effects in injury prevention and recovery.

Previous examinations and the selection of young athletes are of great importance in the prevention of sports injuries. These methods are used to determine who is physically qualified to participate in sports and to eliminate those who are unfit, as well as to appoint a particular type of sport to those who do qualify, and to determine the actions that would help in bringing the young athletes to a state in which their participation in any sport would become possible without any risks of injury or occurrence of chronic damage, which is especially important in the periods of intensive growth [14].

Competitive readiness is the result of training, fitness and experience in sports. Sports technique is also of importance as it is the result of training and good guidance, and it allows the performance of the most difficult actions with minimal effort. Special attention should be paid to strained regions, particularly to the strain of the muscle groups, which need to be subjected to a special regime of exercise. Overtraining represents a major threat to athletes, as the muscles then become more susceptible to injury. Athletes show hypersensitivity to infections and their wounds and fractures heal more slowly, since great physical efforts reduce body's immune power [15]. In addition, sports venues must meet all the requirements of safe practice in sport. Furthermore, the set of sport and safety equipment in every sport is defined by the relevant regulations. Athletes themselves, but also their coaches, referees and sports physicians take responsibility for the lack of application and proper usage of the protective sports equipment. The proper usage of preventive bandages can help prevent or reduce the occurrence of ligament, tendon, and even bone injuries, such as boxer fist bandages, which are required by rules [16].

A significant factor in the rehabilitation of injury is a premature strain in non-recovered athletes which often leads to greater and more serious injuries. In a healthy sports team, a doctor and a coach cannot be on two opposing sides, ie. they cannot and should not be rivals, as both need to work in the interests of athletes, primarily. On the other hand, athletes must strive to take their self-control to the highest level possible, while preventing hurting themselves or the opponents.

The safety of competitors depends on the degree of the organization of preventive measures and the professional level of these measures. Their training, as well as the improved food quality, extend the limits of physical capacity and allow better adaptation of tissues and the whole body to the increasing demands and strain. It is wrong to believe that the healing and rehabilitation of injured athletes can be more rapid than the biological laws of the human body allow [4].

The assessment of the period in which the athlete will not be able to compete is based on the accurate diagnosis of the injury. Injured athletes react differently to the fact that they were injured, and their reaction depends on their current condition and their personalities. Their reaction may be affected by their position in the team, the pressure from the coaches and members of the 
team management, the public pressure, money, the desire to continue competing, etc. $[5,13]$. There are several basic reactions of injured athletes [17]. With the adequate response the athlete is aware of the fact that he was injured, understands the need for proper treatment of his injury and is ready to cooperate with the doctor and other medical staff in the club or out of it. In the case of the simulation and the dissimulation of injury, which is more often seen in young athletes, the help of other medical experts should be sought [18].

The real assessment of the competition ability may be given only by a doctor, based on several elements: the nature of injury, pain sensitivity, time factor, the comparison with the limb in normal condition and functional tests. In severe injuries (fractures and dislocations) the question of the duration of treatment is almost never posed; rather the conventional rules and criteria of the rehabilitation of such injuries are accepted. The problems arise in the cases of light injuries, which are the most common in athletes and are the most common reason for the absence from the sports field. If we take into account that the healing of the skin after suture wounds, takes 8-10 days, it is obvious that the healing of subcutaneous structures takes at least as much [19]. The rehabilitation period is required right after. The sports participation of the injured athlete, just after he was given the first aid or after a short recovery period, with the still existing hematoma, swelling and pain, is a mistake made by both doctors and trainers and shows their indifference towards the young person. Injections for pain relief, or local anesthetics applied directly onto the injury in order for the athlete to not feel pain while performing is unethical and punishable as a criminal act.

\section{CONCLUSION}

The scope and frequency of sports injuries can be affected by a number of factors, such as poor fitness, muscle imbalance, anatomical abnormalities, poor nutrition and the period of intensive growth. Our results show that in the observed subjects the largest number of athletes sustained injuries while skiing, that the injuries were relatively minor and mostly distortions, dislocations and ligament ruptures, and that the injured athletes were usually between 21 and 30 years of age. After the care and treatment of the injuries the athletes were sent to rehabilitation, which was followed by the physician's assessment of the competitive ability of the individuals based on the nature of the injury, the pain sensitivity, the time factor, comparison with the healthy limb and the functional testing. Proper evaluation of competitive ability after injury is an important factor in the prevention of possible injuries in the later sports activities of the individual.

\section{REFERENCES}

1. Mayer GD, Ford KR, Paterno MV, Nick TG, Hewett TE. The effects of generalized joint laxity on risk of anterior cruciate ligament injury in young female athletes. Am J Sports Med 2008; 36:1073-1080.

2. Brandes L, Franck E, Nuesch S. Local heroes and superstars-An empirical analysis of star attraction in German soccer. J Sport Econ. 2008;9(3):266-286.

3. Vaeyens R, Lenoir M, Williams AM, Philippaerts RM. Talent identification and development programmes in sport-Current models and future directions. Sports Med. 2008;38(9):703-714.

4. Faigenbaum AD, Kremer WJ, Blimkie CJR, Jaffreys I, Micheli LJ, Nitka M, Rowland TW. Youth resistance training: Updated position statement paper from the national strength and conditioning assotiation. J Strength Cond Res 2009; 23:560-579.

5. Lauersen JB, Bertlesen DM, Andersen LB. The effectiveness of exercise interventions to prevent sports injuries: a systematic review and meta-analysis of randomised controlled trials. Br J Sports Med 2013; doi:10.1136/bjsports-2013-092538

6. Rubini EC, Costa ALL, Gomes PSC. The effects of stretching on strength performance. Sprot Med 2007; 37:213-224.

7. Thacker SB, Gilchrist J, Stroup DF, Kimsey CD. The impact of stretching on sports injury risk: A systematic review of the literature. Med Sci Sports Exer 2004; 36:371-378.

8. Castagna C, Abt G, D'Ottavio S. Activity profile of international-level soccer referees during competitive matches. J Strength Cond Res. 2004;18(3):486-490.

9. Small K, McNaughton L, Matthews M. A systematic review into the efficacy of static stretching as part of a warm-up for the prevention of exercise-related injury. Res Sport Med 2008; 16:213-231.

10. Zinn C, Schofield G, Wall C. Development of a psychometrically valid and reliable sports nutrition knowledge questionnaire. J Sci Med Sport. 2005;8(3):346-351

11. Aaltonen S, Karjalainen H, Heinonen A, Parkkari J, Kujala UM. Prevention of sports injuries. Systematic review of randomized controlled trials. Arch Int Med 2007; 167:1585-1592. 
12. Yeung SS, Suen AM, Yeung EW. A prospective cohort study of hamstring injuries in competitive sprinters: preseason muscle imbalance as a possible risk factor. Br J Sports Med. 2009;43(8):589-594.

13. Askling $\mathrm{C}$, Saartok $\mathrm{T}$, Thorstensson A. Type of acute hamstring strain affects flexibility, strength, and time to return to pre-injury level. Br J Sports Med. 2006;40(1):40-44.

14. Emery CA. Identifying risk factors for hamstring and groin injuries in sport: a daunting task. Clin J Sport Med. 2012;22(1):75-77.

15. Wang $\mathrm{H}$, Zheng $\mathrm{N}$. Knee rotation and loading during spin and step turn. Int J Sports Med. 2010;31(10):742-746.

16. Blake C, Sherry J, Gissane C. A survey of referee participation, training and injury in elite gaelic games referees. BMC Musculoskelet Disord. 2009;10:74. doi: 10.1186/1471-2474-10-74.

17. Wright JM, Webner D. Playing Field Issues in Sports Medicine. Curr Sports Med Rep. 2010; 9(3):129-133.

18. Farkadin AJ, Gabbe BJ, Cameron PA. Does warming prevent injury in sport? J Sci Med Sport 2006; 9:214-220.

19. Engebresten AH, Myklebust G, Holme I, Engebresten L, Bahr R. Intrinsic risk factors for hamstring injuries among male soccer players. A prospective cohort study. Am J Sports Med 2010; 38:1147-1153.

\section{SRPSKI}

\section{KVANTITATIVNA ANALIZA SPORTSKIH POVREDA U KOSOVSKOJ MITROVICI}

Stanić $D^{1}{ }^{1}$, Božović A. ${ }^{2}$, Vasić A. ${ }^{2}$

${ }_{1}^{1}$ Fakultet fizičkog vaspitanja i sporta, Univerzitet u Istočnom Sarajevu, Istočno Sarajevo, Republika Srpska

${ }^{2}$ Medicinski Fakultet Univerziteta u Prištini, Kosovska Mitrovica, Srbija

\section{SAŽETAK}

Obim $\mathrm{i}$ učestalost povređivanja kod sportista zavise od brojnih egzogenih i endogenih faktora kao što su loša kondicija, mišićni disbalans, anatomske anomalije, nutritivni faktori i period rasta. Nakon zbrinjavanja i lečenja sportske povrede sledi rehabilitacija i procena takmičarske sposobnosti pojedinca od strane lekara na osnovu prirode povrede, bolne osetljivosti, vremenskog faktora, poređenjem sa zdravim ekstremitetom, funkcionalnim ispitivanjima. $U$ ovoj smo studiji proučavali učestalost povređivanja i najčešće lokalizacije povrede kod sportista iz Kosovske Mitrovice. Naši rezultati pokazuju da je pravilna evaluacija takmičarske sposobnosti nakon povrede važan faktor prevencije eventalnog povređivanja u kasnijim sportskim aktivnostima pojedinca.

Ključne reči: sport, povreda, prevencija 